\title{
Characterizing the Sharing Economy State of the Research: A Systematic Map
}

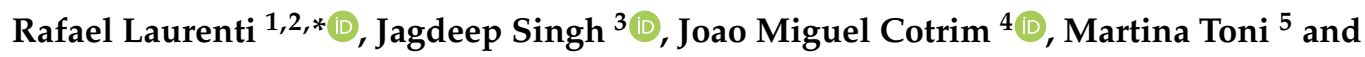 \\ Rajib Sinha ${ }^{6}$
}

1 IPD Integrated Product Development, MMK Department of Machine Design, KTH Royal Institute of Technology, 11428 Stockholm, Sweden

2 HERUS Laboratory for Human Environment Relations in Urban Systems, EPFL Swiss Federal Institute of Technology Lausanne, 1015 Lausanne, Switzerland

3 The International Institute for Industrial Environmental Economics (IIIEE), Lund University, 22100 Lund, Sweden; jagdeep.singh@iiiee.lu.se

4 ISCTE-IUL Business School, University of Lisbon, 1649-004 Lisbon, Portugal; joao_miguel_cotrim@iscte-iul.pt

5 Department of Business Studies, University of Roma Tre, 00154 Roma, Italy; martina.toni@uniroma3.it

6 SEED Department of Sustainable Development, Environmental Science and Engineering, KTH Royal Institute of Technology, 11428 Stockholm, Sweden; rajibs@kth.se

* Correspondence: rafa@kth.se

Received: 12 September 2019; Accepted: 11 October 2019; Published: 16 October 2019

\begin{abstract}
The sharing economy is an emerging niche for innovation capable of disrupting established socio-technical and economic regimes. Because of this potential to cause radical changes in a wide array of domains, research in multiple disciplines addressing various aspects entailing this phenomenon is proliferating. In this emerging body of literature, the understanding and framing of the sharing economy are often different. Without knowledge about the current state of the research related to the sharing economy, delineating research trends, gaps, and needs for directing effectively primary research are not possible. This study aimed to synthesize the state and distribution of existing publications related to the sharing economy in multiple disciplines. We used the systematic mapping technique to scope, identify, and classify the publications at a fine level of granularity. We reviewed 589 journal articles (published from 1978 to 2017), and 454 met the selection criteria. The journal articles reviewed were published in 284 different journals. Intriguingly, 15 journals published five to 13 publications each and 221 journals had a single article about the topic. Journals belonging to the subject areas "business, management and accounting" (42.1\%) and "social sciences" $(35.2 \%)$ published more than $70 \%$ of the reviewed publications. Accommodation $(19.8 \%)$ and car and ridesharing $(17.2 \%)$ were the two most prominent sectors; $50.2 \%$ of the publications addressed C2C transactions (10.6\% B2C, $24.4 \%$ more than one type); $62.3 \%$ were about accessing resources, and $5.1 \%$ concerned transfer of ownership (i.e., second-hand or donation); and 19.2\% covered access and transfer of ownership simultaneously. While empirical studies were the majority (53.1\%, when comparing with conceptual ones), qualitative approaches were most common (51.5\% against $24.9 \%$ quantitative and $17.4 \%$ mixed methods). Literature review $(22.9 \%)$, survey $(13.2 \%)$, case study $(7.3 \%)$ and interview $(7 \%)$ were the most frequently used methods. User behavior $(26.4 \%)$, business models and organizational aspects $(22.7 \%)$, institution and governance system $(18.7 \%)$, conceptualization matters $(17 \%)$, and sustainability evaluation $(15.3 \%)$ are research clusters identified from a grounded approach. The link between user behavior and net environmental impacts of sharing options was the largest gap found in the research needing attention from a sustainability perspective. Accordingly, multidisciplinary investigations quantifying behavioral root causes, magnitude, and likelihood of environmental rebound effects using real-world data are strongly encouraged.
\end{abstract}


Keywords: sharing economy; collaborative consumption; collaborative economy; systematic map; sustainability

\section{Introduction}

Privately owned resources such as everyday objects and tools, large consumer goods, and even skills were commonly shared among neighbors, family, and friends, in a time when material abundance was not so universal as today. An extraordinary increase of material affluence in wealthy societies, driven by a combination of contributing factors, such as, profitability targets as the main driver in business, mass production, easy access to natural resources, and availability of cheap labor [1,2], has allowed almost every household to potentially be able to afford and privately own their own resources. Consequently, private resources ceased to be collectively shared. Because most resources are not in use all of the time, an enormous idle capacity has been created [3].

More recently, a combination of factors involving this phenomenon of plentiful idle resources and the popularization of ICT tools among consumers contributed to the re-emergence of collaborative ways of consumption, now in market niches often referred to as sharing economy or collaborative consumption. In this "novel" socioeconomic paradigm, traditional sharing, bartering, lending, trading, renting, gifting, and swapping were redefined through ICT [4]. The extension of the act of sharing from familiar ties towards a network of (unknown) peers, represented a radical breakthrough induced by the web 2.0. Innovative businesses enabled the exchange of underutilized resources among users (peer-to-peer) via online platforms [5].

The modern sharing phenomenon has been described through quite a few inter-related concepts and a plethora of concomitant definitions [6-8]. Today, the sharing economy is often presented as a "confusing", "ill-defined" or even an "umbrella" concept, with as many interpretations as applications exist [9-11]. The growing body of literature in different disciplines reflects the endless (and useless) debates and conflicting definitions and segmentation for new sharing and exchange. Examining attributes of publications related to the phenomenon can help direct the trajectory of the field to more constructive matters by clarifying research gaps and needs.

The aim of this study is, therefore, to describe and "map" research about the sharing economy. We use the systematic mapping technique [12] to scope, identify, and classify publications referred as sharing economy at a fine level of granularity. Relevant publications are categorized and presented in the form of a searchable database. The resulting database can be used to identify knowledge gaps to inform primary research, other research synthesis methods such as synopses of evidence, and synthesis and evaluation methods such as a systematic review. Hence, this database may be of potential interest not only for researchers from diverse fields looking at distinct characteristics of the sharing economy but also to a wide range of stakeholders, including policymakers, consumers, nongovernmental organizations, authorities, and research funding bodies.

\section{Theoretical Background}

Sharing is the universal form of human economic behavior, distinct from and more fundamental than reciprocity. It has also probably been the most basic form of economic distribution in hominid societies for several hundred thousand years [13]. Social networks and the development of ICT changed the way people communicate and interact worldwide paving the way to the modern sharing phenomenon $[4,5]$. Innovative businesses exploit this market opportunity by creating a virtual space (online platforms) for enabling underutilized resource (information and assets) exchange among users (consumer-to-consumer, $\mathrm{C} 2 \mathrm{C}$ ) on the internet.

Multiple and distinct events of legitimacy, mechanisms. and claims have characterized the evolution of the phenomenon of consumers sharing resources [14]. Entrepreneurial organizations, consumers, and other key stakeholders, namely, the scientific community, investors, and the media, 
have established novel complex interactions. This new structure has led to the emerging behaviors about identity claims (self-referential) and legitimacy granting (from stakeholders). Intriguingly, pioneering organizations (for- and not-for-profit) of the modern sharing phenomenon (e.g., Airbnb, Zipcar, Timebanks, Make:markerspaces) do not state themselves as a sharing economy category business, whereas a vast range of stakeholders, external actors, and interested audiences have granted legitimacy to these organizations.

Several scholars have tried to grasp what the phenomenon of sharing is and provide a definition for it, however, scholars have either adopted similar terms to describe distinct contexts or used different words to name similar instances. Noteworthy, historical conceptions of sharing resources are described in the classic work of the French sociologist Marcel Mauss [15] and American scholar Lewis Hyde [16,17]. Mauss laid the foundation of social theories of reciprocity and gift exchange, and Hyde offered a thoughtful analysis of the social function of goods and services exchanged outside the structure of the market, both using "sharing" to connote gift exchange. Probably the first scholar to use the term "sharing economy" was Lawrence Lessig, Harvard Professor and founder of Creative Commons, in his seminal book, Remix [18]. Professor Lessig used the term sharing economy in the context of culture and art rather than physical resources. Then, Professor Russel Belk [19] and Rachel Botsman and Roo Rogers [4] conceptualized definitions and a segmentation to the phenomenon under the umbrella "collaborative consumption", a term that drew much attention from academia and business.

Belk [19] distinguishes in two main periods, before and after the web 2.0. Firstly, the act of sharing already occurred, but it was mainly without monetary exchange and enclosed among relatives, friends, and acquaintances. On this regard, Belk [19] basically refers to sharing economy as "the act and process of distributing what is ours to others for their use and/or the act and process of receiving or taking something from others for our us". In this case (before web 2.0), sharing represents an ancient type of consumption. After web 2.0, sharing tangible and intangible assets became a widespread trend and economic, social, and environmental drivers contribute to its diffusion in order to encourage sustainable behaviors.

Botsman and Rogers [4] interpreted collaborative consumption as the phenomenon of consumers accessing underutilized resources (goods, services, information, skills, time, and money) in creative and innovative ways, reinventing traditional market behaviors (renting, lending, swapping, sharing, bartering, and gifting) and enabling access over ownership. This interpretation implies maximizing the utilization of assets through efficient models of redistribution and shared access. According to the authors, collaborative consumption is one of the four instances of what they called "collaborative economy"; collaborative production, collaborative education, and collaborative finance being the other three. The collaborative economy was defined as "an economy built on distributed networks of connected individuals and communities versus centralized institutions, transforming how we can produce, consume, finance, and learn" [4]. A common characteristic of the four is the presence of a network of peers, trust, and idle resources.

The segmentation offered by Botsman and Rogers's overlaps previous attempts to define the phenomenon of sharing and precedent studies used the terms with far too little rigor. Moreover, the fact that the term "sharing" acquired a broader meaning with the advent of social commerce has contributed to the lack of consistent use of the terms. The main consequence is that sharing has been associated simultaneously to gift exchange (donation), asset exchange (second-hand buy and sell), renting, and co-owning between peers (P2P), business-to-consumer (B2C), or business-to-business (B2B) via the internet.

For this reason, there might be a need for further strict definitions. More recently, further attempts to define the field have been made. Frenken and Schor [3], for example, provide a marked distinction among definitions, building a boundary between what sharing economy is and what it is not related to various forms of platform economy such as product-service systems (PSS), on-demand economy, and second-hand economy. According to the authors, in a sharing economy, consumers 
grant each other temporary access to under-utilized physical assets ("idle capacity"), possibly for monetary compensation. Thus, in their definition, the distinct features of the sharing economy involve consumer-to-consumer interaction (C2C), temporary access, and physical goods. Curtis and Lehner [20] further identify some of the key semantic properties of the sharing economy for sustainability such as non-pecuniary motivation for temporary ownership and rivalrous (i.e., prevents simultaneous use by other users).

Despite that the use of the terms have changed over a short period, they lack more stringent and clear-cut definitions. It is not our purpose in this paper, however, to try to come up with new and more specific definitions, but rather to examine how the terms "sharing economy", "collaborative economy", and "collaborative consumption" have been used by scholars. Nevertheless, to establish the scope of the present paper and the unit of analysis, we have interpreted the phenomenon of modern sharing as an economic model based on sharing underutilized assets (products, spaces, and skills) for monetary or nonmonetary benefits mediated by the internet. To systematically dissect and structure this emerging research field is the topic of this paper.

\section{Materials and Methods}

\subsection{Systematic Mapping}

Systematic mapping studies are designed to give an overview of a research area through classification and coding [21]. It involves searching the literature in order to know what topics have been covered, and where the literature has been published [22]. Systematic mapping was developed in social sciences in response to a lack of empirical data when answering questions using systematic review methods, and a need for a method to describe the literature across a broad subject of interest [23]. The method has been recently adapted to be used to generate evidence synthesis in environmental sciences [12]. Currently, systematic mapping is used in social and environmental sciences to provide an overview of evidence for broad research questions.

Systematic mapping, like a systematic review, is a robust, repeatable, and transparent scientific method used to identify and categorize available literature on a particular topic [24]. It uses established searching protocols and has rigorous criteria for inclusion or exclusion [12].

Although a systematic mapping study and a systematic literature review share some commonalities (e.g., concerning searching and study selection), they are different in terms of goals, and thus approaches to data analysis [12]. Systematic reviews aim at synthesizing evidence and also consider the strength of evidence, whereas systematic maps are primarily concerned with structuring a research area and do not usually attempt full data extraction or critical appraisal of the relevant research [21]. Systematic mapping does not attempt to answer "closed-framed" questions (where all the critical elements are clearly specified are termed) as systematic review does, but instead describes the state of knowledge for "open-framed" question (questions that lack specification of some critical elements) or topics [12], identifying the nature, volume, and characteristics of research in a chosen field [24]. Moreover, a systematic map can also provide the basis for an informed decision about whether to undertake the in-depth review on all of the studies or just a subset. Mapping studies enable the contextualization of in-depth systematic literature reviews within broader literature and identification of gaps in the evidence base [25].

We adapted the guidance for systematic mapping developed in the fields of social sciences [23] and environmental sciences [12], following the steps shown in Figure 1. 


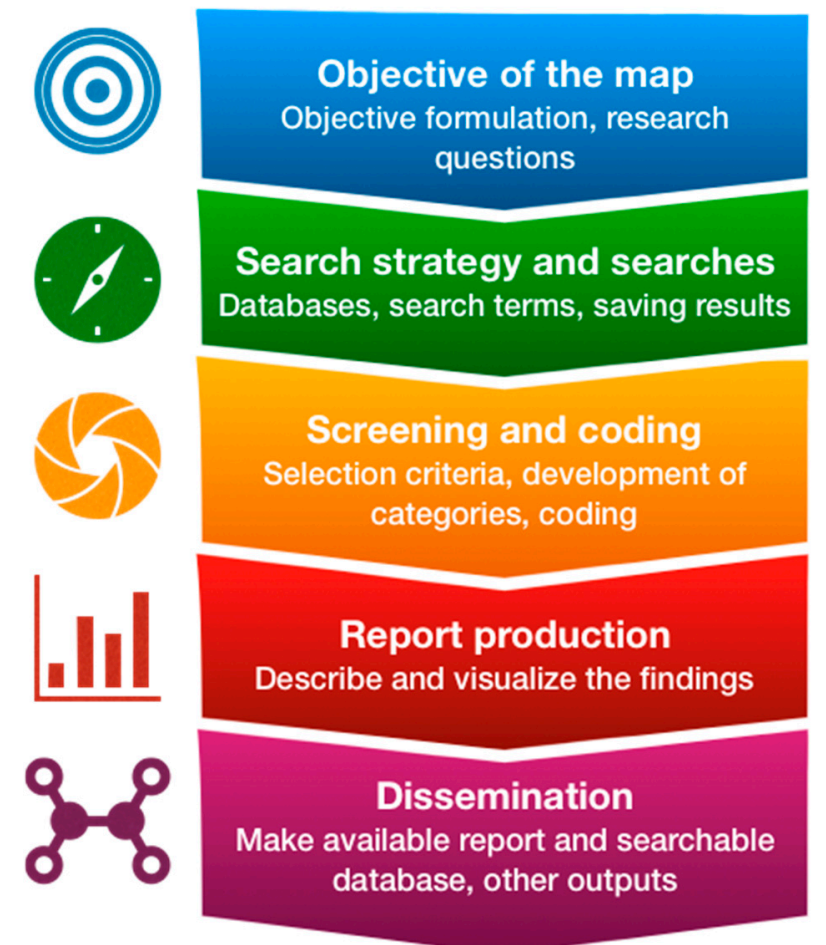

Figure 1. Steps of the systematic mapping of this study.

\subsection{Objective of the Map}

\subsubsection{Objective Formulation}

The terms "sharing economy", "collaborative consumption" and "collaborative economy" have been commonly used in recent years to refer to a proliferation of initiatives, business models, and forms of work. These include the development of far-reaching corporate digital platforms that have become a means of organizing cooperative practices, and the local, regional, and community-led collaborative initiatives in sectors such as housing, tourism, transport, social enterprise, culture, and the arts. Researchers from many disciplines have studied this phenomenon from diverse perspectives.

This study aims to identify and systematically map published research to address the following objectives (Os):

O1. To characterize and map research associated with the sharing economy phenomenon, describing the developments, themes and recurrent features of the research;

O2. Provide a map that is searchable by topic;

O3. Inform future research synthesis and evaluation methods such as systematic review;

O4. Identify knowledge gaps in order to inform future primary research.

\subsubsection{Research Questions}

The research questions (RQs) that guided the construction of the map were:

RQ1. In which knowledge areas, by which journals and when research on sharing economy has been published?

RQ2. Which sharing sectors and items have been studied?

RQ3. What types of transactions (e.g., C2C, B2C, B2B, B2C) have been said to comprise the sharing phenomenon?

RQ4. What research methods and sources of data have been used?

RQ5. What topic areas have been focused? 


\subsection{Search Strategy and Searches}

\subsubsection{Databases}

The search aimed to include the online databases Scopus and ISI Web of Science (WoS) which cover the breadth and depth of available literature on the unit of analysis of this study.

\subsubsection{Search Terms}

We scoped to identify suitable relevant key terms to include in the finalized search string. First, we adopted the seven terms related to "collaborative economy" described by Botsman and Rogers [4] to initially scope the field, and used them in individual searches in the Scopus and WoS database. We performed the search in August 2018 and restricting the results to items published before the year 2018. Table 1 presents the keywords used and the number of hits obtained.

Table 1. Keywords used and hits obtained during the initial scooping of the field.

\begin{tabular}{ccc}
\hline Search String & Scopus Hits & WoS Hits \\
\hline "collaborative economy" & 96 & 72 \\
"collaborative consumption" & 181 & 184 \\
"sharing economy" & 691 & 539 \\
"collaborative production" & 359 & 199 \\
"peer economy" & 20 & 16 \\
"collaborative finance" & 4 & 3 \\
"collaborative education" & 240 & 163 \\
TOTAL & 1591 & 1176 \\
\hline
\end{tabular}

Then, we combined all the seven terms in a single string and obtained 1452 and 1009 hits. We observed that only 139 and 167 items were overlapping within the keywords used in Scopus and WoS database, respectively. This result indicated that each of these keywords (at least those with most hits) might represent individual research clusters. To check this assumption and aid the selection of the keywords, we produced term maps of co-occurrence of terms in the title, abstract, and authors' keywords of the publications using the software VOSViewer [26], see Figure 2.

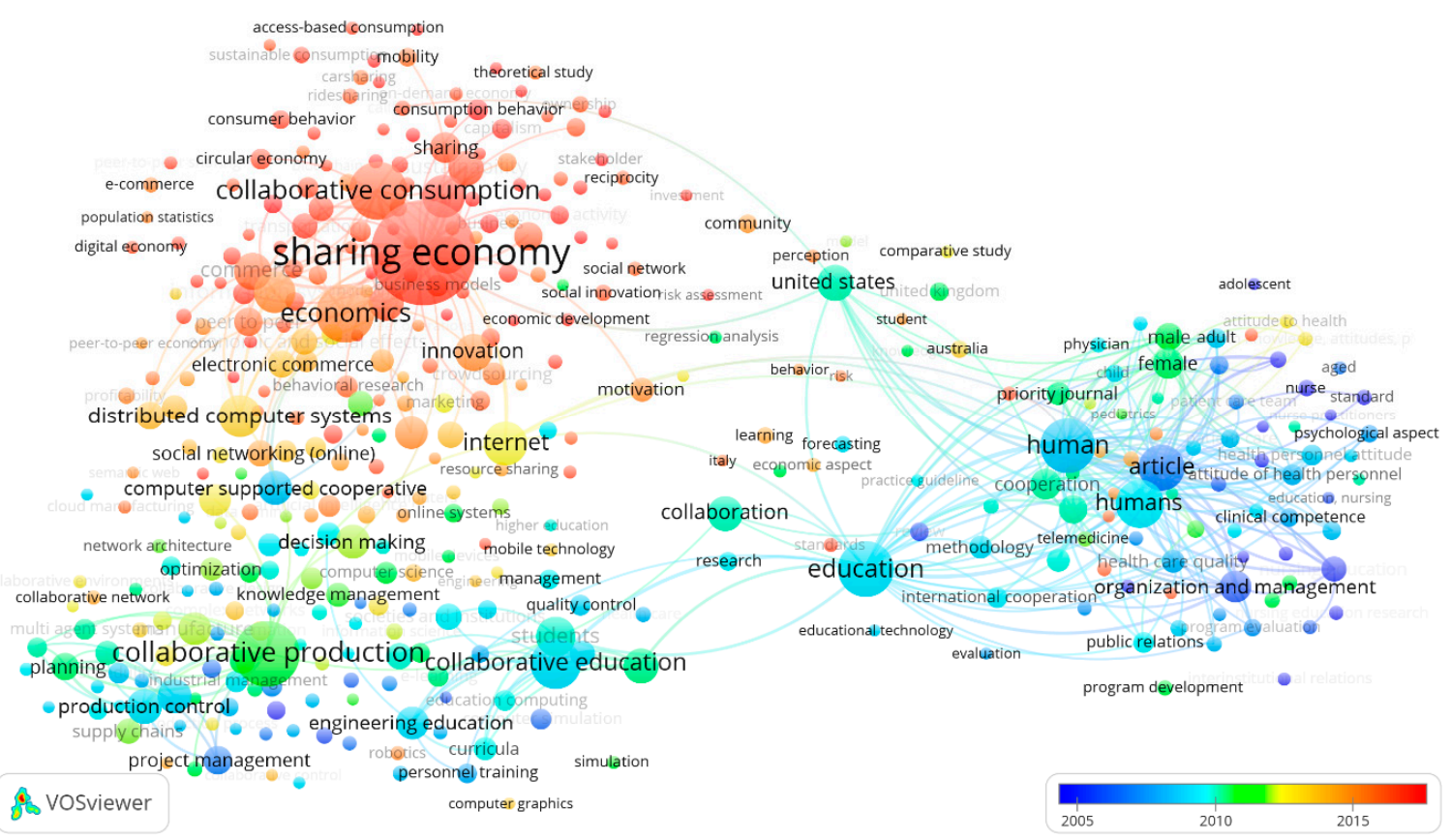

Figure 2. Temporal co-occurrence term map of the keywords shown in Table 1. 
The network visualization (Figure 2) shows that three main clusters exist as follows:

1. Collaborative education;

2. Collaborative production;

3. Sharing economy, encompassing collaborative consumption, and collaborative economy.

The publications related to collaborative education have emerged around the years 2005 to 2008 (see Figure 2); subsequently, about the year 2010, research probing collaborative production began to develop. Then, after the year 2012, publications refereeing to collaborative economy, collaborative consumption, and sharing economy took over the research field. Sharing economy is currently the most used term in publications.

It appeared that the terms the search strings "peer economy" and "collaborative finance" were of no significant relevance for our study due to their relatively low number of publications (see Table 1). Moreover, analyzing the term map shown in Figure 2, research on "collaborative education" and "collaborative production", proved to be of low relevance to the core of the sharing economy research. Then, we decided to produce a new term map only including the keywords "sharing economy", "collaborative economy", and "collaborative consumption" to check whether these keywords can be seen as a single nucleus that unifies various research areas. Figure A1 of Appendix A presents the term map developed. Those three keywords formed a consistent system boundary for the study. Therefore, we decided to proceed only with those keywords. Table 2 displays the finalized search string and the number of publications in Scopus and WoS.

Table 2. Finalized search string following scoping in Scopus and Web of Knowledge.

\begin{tabular}{ccc}
\hline Search String & Scopus Hits & WoS Hits \\
\hline $\begin{array}{c}\text { "sharing economy" OR } \\
\text { "collaborative economy" OR } \\
\text { "collaborative consumption" }\end{array}$ & 837 & 662 \\
\hline
\end{tabular}

\subsubsection{Saving Results}

We imported the results retrieved from Scopus and Web of Knowledge (1499 publications) into Mendeley, a software to manage references. The automatic function in the software removed all duplicates in the dataset. A total of 942 unique publications remained. We than exported the cleaned dataset to a Google ${ }^{\circledR}$ Sheet so that the members of the systematic mapping team could build the database simultaneously. The Google Sheet contained the following primary bibliographic information: item type (journal article, conference paper, book, etc.), publication year, author, title, where it was published (e.g., journal name, conference name, and book title), abstract, pages, issue, volume, publisher, place, language, and DOI. Table A1 of Appendix A shows a breakdown by publication type.

\subsection{Screening and Coding of Titles and Abstracts}

\subsubsection{Selection Criteria}

We decided to extract information for the coding only of journal papers $(n=618)$ since this is the highest quality of publication among the other publication types. Journal papers were assigned as excluded from the database when their main topic was not about the sharing economy, collaborative consumption, or collaborative consumption (false positive).

\subsubsection{Development of Coding Categories}

We adapted the classification constructs for the sharing economy proposed by Hamari and colleagues [27], Plewnia and Guenther [28], and Trenz and colleagues [29]. In addition to what these studies used, we added publication areas and general theme as code categories. Table 3 shows the coding categories, their definition, subcategories of codes, and references used. 
Table 3. Codes used for classifying the sharing economy publications.

\begin{tabular}{|c|c|c|c|}
\hline Coding Category & Definition & Code Subcategory & References \\
\hline Sharing sector & $\begin{array}{l}\text { Business sector that the article } \\
\text { refers to }\end{array}$ & $\begin{array}{l}\text { Several, coded following a } \\
\text { grounded approach }\end{array}$ & [28] \\
\hline Actors involved & $\begin{array}{l}\text { Describes the actors involved in } \\
\text { the transaction }\end{array}$ & $\begin{array}{l}\text { Consumer-to-consumer } \\
\text { Business-to-consumer } \\
\text { Business-to-business } \\
\text { More than one type }\end{array}$ & [29] \\
\hline Type of behavior & $\begin{array}{c}\text { Indicates the type of trading } \\
\text { activity }\end{array}$ & $\begin{array}{c}\text { Buying used } \\
\text { Swapping } \\
\text { Borrowing } \\
\text { Renting } \\
\text { Donating } \\
\text { More than one type } \\
\text { Not clear }\end{array}$ & [27] \\
\hline Acquisition mode & Mode of exchange & $\begin{array}{l}\text { Transfer of ownership } \\
\text { Access over ownership } \\
\text { More than one mode } \\
\text { Not clear }\end{array}$ & [27] \\
\hline Compensation scheme & $\begin{array}{l}\text { Describes how the sharing } \\
\text { transaction is compensated }\end{array}$ & $\begin{array}{l}\text { Monetary } \\
\text { Nonmonetary } \\
\text { Not clear }\end{array}$ & [29] \\
\hline Publication area & $\begin{array}{l}\text { Knowledge area of the journal } \\
\text { that the article was published. It } \\
\text { can be seen as the knowledge } \\
\text { paradigm under which the } \\
\text { publication was written }\end{array}$ & $\begin{array}{l}\text { Several, coded accordingly to } \\
\text { Scopus and WoS classification } \\
\text { (e.g., social sciences, computer } \\
\text { sciences, multidisciplinary) }\end{array}$ & Scopus and WoS \\
\hline $\begin{array}{l}\text { Themes in sharing } \\
\text { economy research }\end{array}$ & $\begin{array}{l}\text { Describes the general theme of } \\
\text { the publication }\end{array}$ & $\begin{array}{l}\text { Grounded approach of coding } \\
\text { and recoding in an iterative way }\end{array}$ & {$[30,31]$} \\
\hline
\end{tabular}

"Not clear" was used when we could not determine the level of a category from the information contained in the title, abstract, and keywords of the publication.

\subsubsection{Coding}

The title, abstract, and authors' keywords of the 618 journal articles were reviewed and coded accordingly to the code classification in Table 3. It took approximately four months to complete coding for all publications. Twenty-nine (29) items were actually "popular science articles", and 10 were special issue reports, and thus, these were excluded from the review. We identified 102 articles as a false positive, and therefore excluded from the mapping. We excluded another 28 papers because their abstract was not available; and nine entries were special issue editorials. Finally, a total of 453 journal articles remained for review and coding.

The coding team (the authors of this paper) shared a working log, writing the progress, modifications in the working sheet, codes added, essential points to be discussed or check by another member. We visited this working log each time we initiated and reinitiated the coding for acknowledging new updates. We also had virtual follow-up meetings every second week during the coding phase.

Once all papers were reviewed, we imported the Google working sheet into the RStudio software (Version 1.1.463) using the package "googlesheets". We plotted and explored the results of the mapping with the "ggplot2" package. 


\section{Results}

\subsection{Evolution of Publications on the Research Topic}

The data show that the number of publications has grown from 18 studies in the year 2013 to 589 publications in the year 2018 (see Figure 3). This exponential increase in publications indicates that the topic of the sharing economy is an emerging field of the research area. We can see in Figure 3 that the number of publications on the sharing economy suppressed those of older and established research paradigms such as sustainable consumption and product-service system. Moreover, a sharp increase in publications in 2017 occurred not only in the sharing economy field but also in its neighboring field, circular economy.

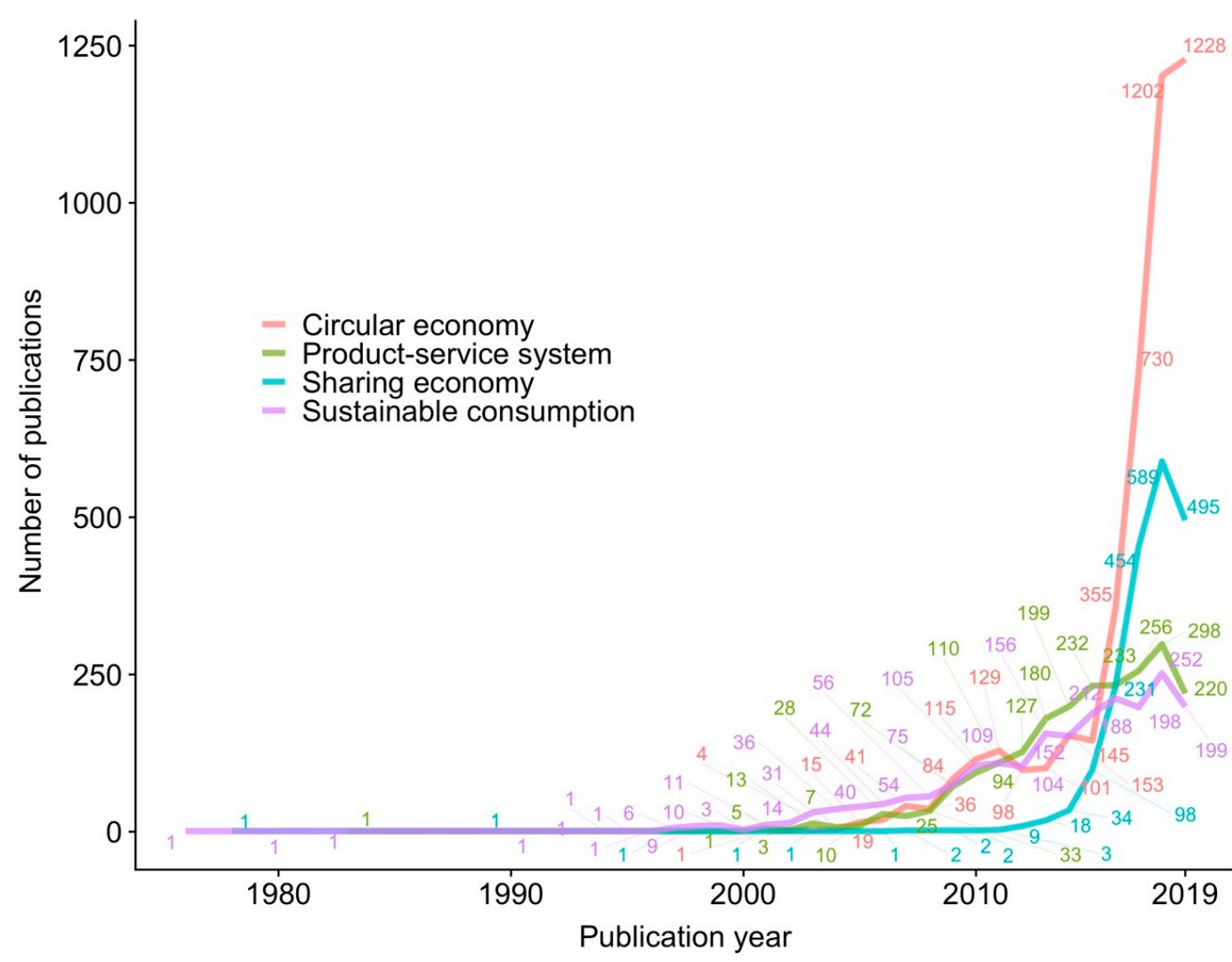

Figure 3. Comparison of the evolution of the sharing economy field with the circular economy, product-service system, and sustainable consumption field. Data retrieved from Scopus on 2 September 2019 ( publications in journal issues of the year 2020 were allocated to the year 2019).

Some pivotal publications are considered foundation in the sharing economy field. Table A2 of Appendix B highlights the top ten most cited publications in Scopus concerning the keywords "sharing economy", "collaborative consumption", or "collaborative economy". In our study, we decided to proceed with these three search keywords that describe the core of the sharing economy research field (cf. Table 2). The use of these terms of describing the research field could be explained by analyzing the most influential publications (cf. Table A2 of Appendix B) and the evolution of the sharing economy publications (Figure 3) over the years. The top-most cited publication "What's mine is yours: how collaborative consumption is changing the way we live" by Botsman and Rogers [4] and older publication by Felson and Spaeth [32] explain the early use of the term "collaborative consumption" in academia. Accordingly, "What's mine is yours" by Botsman and Rogers [4] actively contributed to the increasing number of publications in the area. Furthermore, with the rise of sharing platforms such as Airbnb and Uber over these years, the term "sharing economy" became more popular and an accepted "buzz word" in society. 
The following sections present the results of the classification of the 453 journal articles selected concerning the knowledge area of the journal they were published in, the business sectors they referred to, the actors involved and sharing behaviors that they addressed, the research approach, methods, and data type that they used. We close the results section by showing the research clusters identified through a grounded approach. The resulting database where the 453 articles were classified is available in the Supplementary Material 1 accompanying this study.

\subsection{Knowledge Areas}

The subject areas of the journals determine the nature and type of the scientific contributions of the publications. In this study, we adopted the Scopus classification, which uses a general and a specific category to classify the journals. Concerning a general classification (right-hand side of Figure 4), journals belonging to the subject areas "business, management and accounting" (42.2\%) and "social sciences" (35.1\%) published more than $70 \%$ of the reviewed publications. The publications within "environmental science" and "economics, econometrics and finance", "computer science", and "general engineering" account for $8.4 \%, 5.3 \%, 4.8 \%$, and $4.2 \%$, respectively.

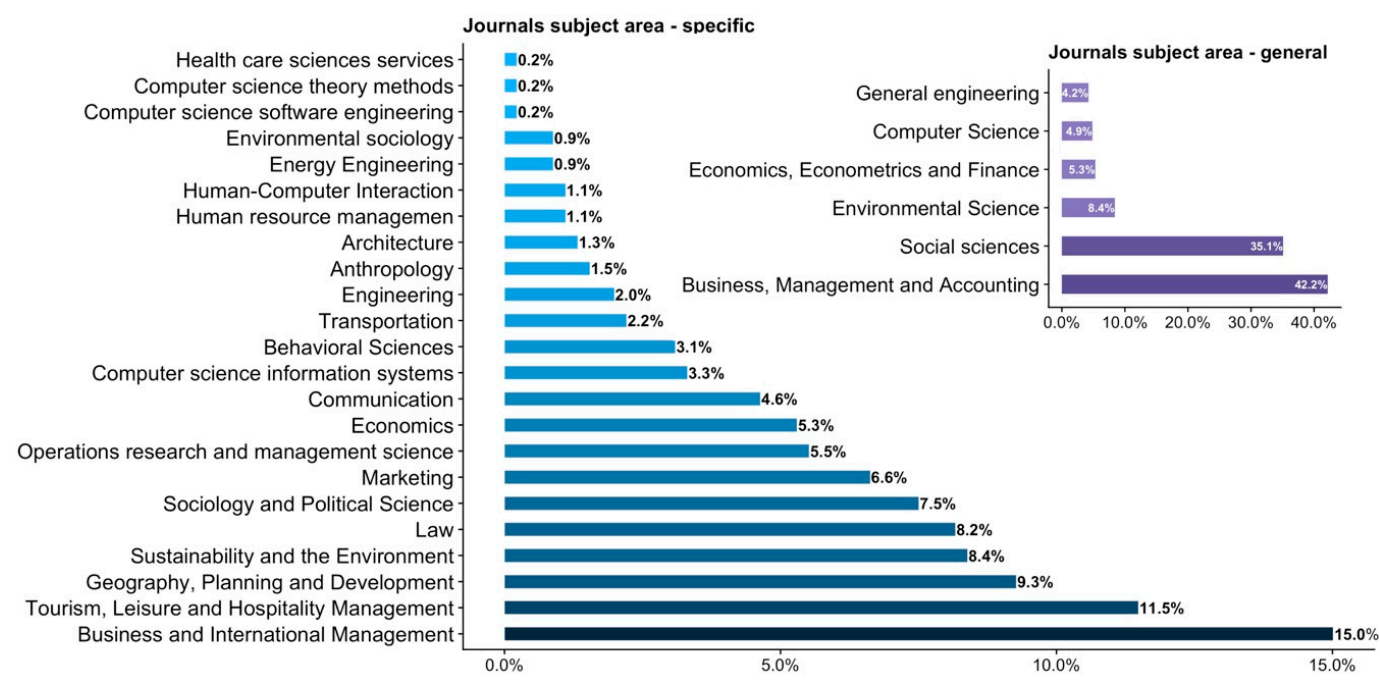

Figure 4. Percentage of publications in subject areas (general and specific).

Concerning specific subject areas (left-hand side of Figure 4), about 35\% of the total publications were in three areas, "business and international management" (15\%), "tourism, leisure, and hospitality management" (11.5\%), and "geography, planning, and development" (9.3\%). Publications in areas such as "sustainability and the environment", "law", "sociology and political sciences", "marketing", "operations research and management science", and "economics" account for between $8 \%$ to $5 \%$ each, whereas "economics" and "social economics" score below 3\% each.

Remarkably, two hundred eighty-four (284) different journals published the 453 journal articles reviewed, 15 journals published between five and 13 publications each, and 221 journals issued a single article about the topic. The International Journal of Contemporary Hospitality Management was the top with 13 articles, followed by the Technological Forecasting and Social Change (11 articles) and the Cambridge Journal of Regions, Economy and Society (10 articles), Environmental Innovation and Societal Transitions (8 articles), Journal of Cleaner Production (8 articles), and Sustainability (8 articles). See Figure 5 for a complete overview of the number of articles published in diverse journals. 


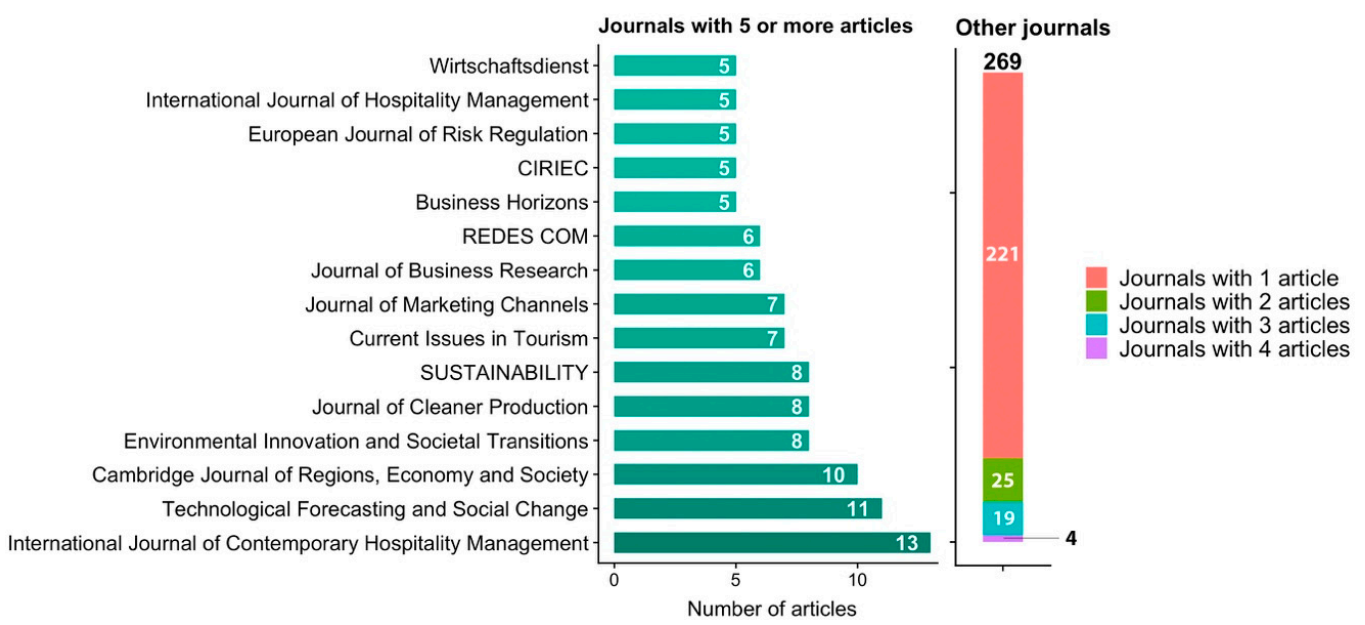

Figure 5. Names of journals with five or more articles (left side) and number of journals with four to one article (right side).

\subsection{Business Sectors}

Shared space (21.4\%) and shared mobility $(18.1 \%)$ are the two main focuses of the majority of the publications. Some of the publications analyzed more than one sectors $(15.4 \%)$, whereas $34.8 \%$ do not specify the sector of application (generic context). The predominant focus of these latter publications was on conceptualization and discourses about the modern sharing phenomenon in general terms. The remaining publications $(10.5 \%)$ were about other intangible assets $(3.1 \%)$, food $(2.6 \%)$, other tangible assets $(2.6 \%)$, finance $(0.7 \%)$, and other sectors $(1.3 \%)$. Table 4 shows the detailed percentage distribution within each business sector. Except for food and finance that refer only to one specific sector (i.e., meal sharing and crowdfunding), the other sectors embed various subsectors. Space contains shared accommodation (19.8\%), coworking office $(0.9 \%)$, and land sharing $(0.7 \%)$; mobility divides car sharing $(17.2 \%)$ and bike sharing $(0.4 \%)$; other intangible assets covers crowdwork $(2 \%)$, time banking $(0.7 \%)$, and energy $(0.4 \%)$; other tangible assets holds clothing $(2.2 \%)$, books $(0.2 \%)$, and furniture $(0.2 \%)$; finally, other sectors entails digital manufacturing $(0.7 \%)$, customs broker $(0.2 \%)$, journalism $(0.2 \%)$, and healthcare $(0.2 \%)$. Hence, shared accommodation and car sharing result to be the main contexts of research application; on the contrary, scarce focus has been employed to other subsectors of space and mobility, such as coworking office and bike sharing, finance, food, other tangible assets, and other intangible assets.

Table 4. Percentage of publications in business sectors identified through the mapping.

\begin{tabular}{cc}
\hline Business Sector & Subsectors \\
\hline Space $(21.4 \%)$ & shared accommodation $(19.8 \%)$ \\
& coworking office $(0.9 \%)$ \\
land sharing/farming $(0.7 \%)$ & car sharing $(17.2 \%)$ \\
bike sharing $(0.4 \%)$ & crowdwork $(2 \%)$ \\
& time banking $(0.7 \%)$ \\
Other intangible assets (3.1\%) & energy $(0.4 \%)$ \\
& meal sharing $(2.6 \%)$ \\
Food $(2.6 \%)$ & clothing $(2.2 \%)$ \\
& books $(0.2 \%)$ \\
Other tangible assets $(2.6 \%)$ & furniture $(0.2 \%)$ \\
& digital manufacturing $(0.7 \%)$ \\
Other sectors $(1.3 \%)$ & customs broker $(0.2 \%)$ \\
& journalism $(0.2 \%)$ \\
Finance $(0.9 \%)$ & healthcare $(0.2 \%)$ \\
Not identified $34.8 \%$ & crowdfunding $(0.9 \%)$ \\
& \\
\hline
\end{tabular}




\subsection{Actors Involved and Types of Resource Exchanges}

Private consumers granting each other access to products or services with monetary compensation are the predominant characteristics of the research field; $50.2 \%$ of the publications reviewed addressed consumers-to-consumer transactions, and $62.3 \%$ were about accessing resources in diverse business sectors. Business-to-consumer transactions covered $10.6 \%$ of the publications, while $24.4 \%$ encompassed more than one type of transaction. Few studies (5.1\%) were about the transfer of ownership (i.e., second-hand or donation) and 19.2\% covered access and transfer of ownership together in the same publication. Accordingly, renting and transactions with monetary compensation comprised $44.1 \%$ and $59.7 \%$ of the publications, respectively. In contrast, few publications mentioned buying used $(1.3 \%)$ and donating $(1.1 \%)$. This is aligned with the definition of sharing economy by Frenken and Schor [3] that state that transactions entailing transfer of ownership belong instead to a so-called "second-hand economy". Furthermore, our results point out that nonmonetary sharing behaviors such as borrowing $(4 \%)$ and swapping $(1.8 \%)$ have received little attention in research. Figure 6 presents the exact percentages for the different types of transactions.

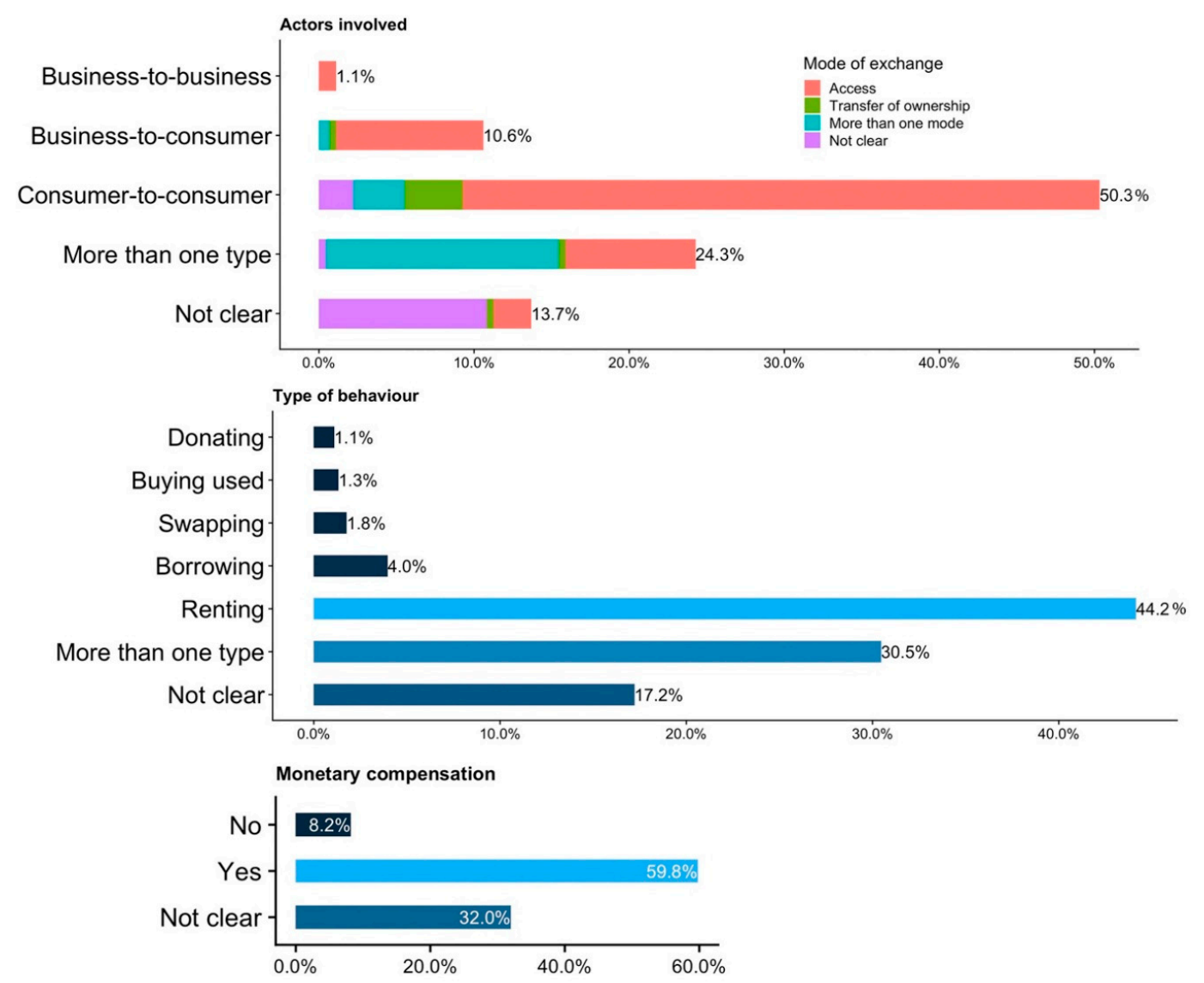

Figure 6. Representation of how publications covered different types of transactions between actors.

\subsection{Research Approach and Methods}

The majority of the reviewed studies were empirical (53.1\%), while qualitative was the most commonly adopted approach (51.5\%). Twenty-seven methods were identified across all disciplines (see Figure 7). The vast extent of these methods were literature review $(22.9 \%)$, surveys $(13.2 \%)$, case studies $(7.3 \%)$, and interviews $(7 \%)$ indicating that major efforts are made to understanding the area and its dynamics; whereas methods based on data mining are less utilized showing the emergence and low data availability of the field. Notably, life cycle assessment, the most popular method to assess the environmental impacts of products and services, appeared in a single publication [33]. Figure 7 shows the precise percentages of the research approach and methods. 


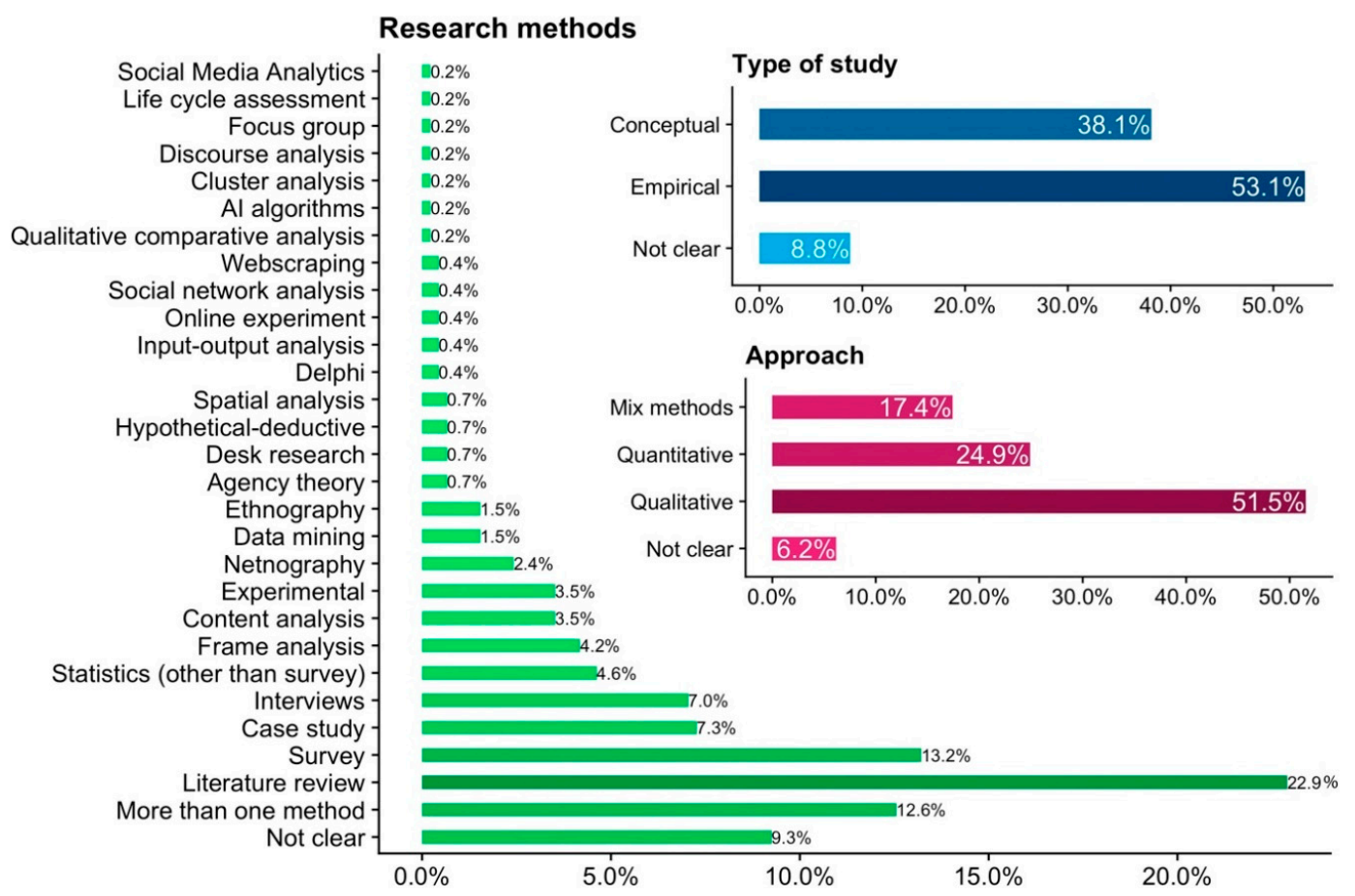

Figure 7. Percentage of conceptual vs. empirical studies, research approach, and methods.

\subsection{Research Clusters and Recurring Themes}

We identified the following five clear research clusters: (1) user behavior $(26.4 \%),(2)$ business models and organizational aspects $(22.7 \%)$, (3) institution and governance system $(18.7 \%)$, (4) conceptualization matters (17\%), and (5) sustainability evaluation (15.3\%). Table 5 shows the recurring themes, the size of each cluster, and example of studies.

Table 5. Five research clusters, respective recurring themes, size, and example of studies. Note that the percentage of the publications designates the cluster size.

\begin{tabular}{|c|c|c|c|}
\hline Research Cluster & Recurring Themes within the Cluster & Cluster Size & Examples of Studies \\
\hline User behavior & $\begin{array}{l}\text { Investigation of preferences and motivation of users and } \\
\text { attitude towards sharing; study of human-computer } \\
\text { interactions; scrutiny of issues related to reputation, risk } \\
\text { and trust and human-computer interaction. }\end{array}$ & $26.4 \%$ & {$[9,27,34]$} \\
\hline $\begin{array}{l}\text { Business models and } \\
\text { organizational } \\
\text { aspects }\end{array}$ & $\begin{array}{l}\text { Development and evaluation of new business models for } \\
\text { sharing; comparison between traditional and sharing } \\
\text { business models; analysis and discussion on emerging } \\
\text { challenges to management. }\end{array}$ & $22.7 \%$ & [35-37] \\
\hline $\begin{array}{l}\text { Institution and } \\
\text { governance system }\end{array}$ & $\begin{array}{l}\text { Proposals for implementation of regulation and laws; } \\
\text { analysis of matters of ethics and labor; discussion on } \\
\text { asymmetric power relationships between actors; } \\
\text { argumentation about societal norms. }\end{array}$ & $18.7 \%$ & [38-40] \\
\hline $\begin{array}{l}\text { Conceptualization } \\
\text { matters }\end{array}$ & $\begin{array}{l}\text { Proposal of definitions of the sharing economy, } \\
\text { collaborative consumption and collaborative economy; } \\
\text { analysis and exploration of the modern sharing discourse; } \\
\text { discussion about what sharing economy is and is not; } \\
\text { debates about the promises and paradoxes of the } \\
\text { paradigm; examination of the societal drivers and barriers } \\
\text { to a transition to and scale up a sharing society. }\end{array}$ & $17 \%$ & {$[3,5,41]$} \\
\hline \multirow[t]{3}{*}{$\begin{array}{l}\text { Sustainability } \\
\text { evaluation }\end{array}$} & \multirow{3}{*}{$\begin{array}{l}\text { Appraisal, discussion and estimation of: } \\
\text { social impacts (penetration of the SE in societal areas; } \\
\text { impact on the job market and working condition); } \\
\text { environmental impacts (estimates on possible adverse } \\
\text { effects caused by sharing/exchanging business models in } \\
\text { the environment); and } \\
\text { economic impacts (measures of business revenue or } \\
\text { economic potential). }\end{array}$} & $\begin{array}{c}15.3 \% \\
\text { Social impacts } \\
(8.4 \%)\end{array}$ & \multirow[t]{3}{*}{ [42-44] } \\
\hline & & $\begin{array}{l}\text { Environmental } \\
\text { impacts }(5.1 \%)\end{array}$ & \\
\hline & & $\begin{array}{c}\text { Economic impacts } \\
(1.8 \%)\end{array}$ & \\
\hline
\end{tabular}




\section{Discussion}

\subsection{Emerging Patterns from the Research Trajectory}

The (un)definitional boundaries offered by the influential articles and authors that have initially shaped the research field may explain the exchangeable use of the terms sharing economy, collaborative economy, and collaborative consumption. Our results indicate that a variety of online platforms for renting, selling, co-owning, and everything in between have embraced these terms to describe their business models. In this sense, the research area is characterized by studies encompassing a rich combination of exchange behaviors, such as renting [45], donating [46], buying and selling second-hand [47], swapping [48], and lending and borrowing [49]; participating actors (e.g., C2C, B2B, $\mathrm{B} 2 \mathrm{C}$, etc.); presence or absence of monetary exchanges; and exchange mode (e.g., transfer of ownership, access). Some of the distinguishing features of the literature are online platforms enabling transactions among strangers [50], decentralized control of business [51], users as independent contractors [52], and democratization of economy [53]. The lack of consistent use of the above terms may suggest that the research area is not only an emerging one but also taking over established research fields, namely, the product-service systems (B2C access via monetary exchange).

Our results also illustrate that the modern sharing phenomenon has radically disrupted the business sectors accommodation and mobility, and is entering an extensive range of different ones (cf. Table 4). The main reasons for this may be ascribed to the use of ICT [54] that has reduced transaction costs of sharing services [51]. Some literature attributes unintended adverse social and environmental effects to these developments and highlights the need for new regulatory mechanisms [55] and value co-creation [56,57]. We also encountered a few prominent studies arguing that the negative sentiments associated with some of the significant sharing organizations such as Airbnb, Uber, and Lyft in the public discourses across countries have influenced the general public perception of the modern sharing phenomenon in society [58,59].

The modern sharing phenomenon has stimulated scientific discussions across multiple disciplines about five research clusters (similar themes, see Table 5), investigated through numerous research methods. Business, management, marketing, and social sciences, in general, are the two dominant subject areas (cf. Figure 4). Nine special issues identified in our mapping also acknowledge the preeminence of these knowledge areas (Table A3 of Appendix B lists the special issues). While empirical studies were the majority ( $53.1 \%$ as comparing with conceptual ones), qualitative approaches were most common (51.5\% against $24.9 \%$ quantitative and $17.4 \%$ mixed methods). Furthermore, literature review, survey, case study, and interview were the most frequently used methods (Figure 7). We can notice that the choice of research methods largely depends upon the unit of analysis (theme). It appears, therefore, that there is a correlation between disciplines, themes, and methods in our mapping.

The nuances of across disciplines and sectors demand an agreed definition of these new phenomena that avoids confusion with other similar business models and enables a congruent account of the sharing economy discourse. Radical framings of sharing economy in academia may clearly define and distinguish the research field. For instance, Steven and Lehner [20] proposed an intentional definition of sharing economy for sustainability as the sharing activity that is IT-enabled, non-pecuniary motivation for ownership (i.e., it leverages the idling capacity), temporary access, durable goods, peer-to-peer or business-to-business, rivalrous. Such radical definition, however, may also disconnect the current dominant understanding of the sharing economy in society. 


\subsection{Research Needs from an Environmental Sustainability Perspective}

Although user behavior is the largest research cluster identified in our mapping, most of the research was done for the accommodation and mobility contexts. Hence, more research on the motivation of users to engage in sharing practices [60] beyond the accommodation and mobility sector is needed. Moreover, a deeper understanding of the differences in motivations to participate in the sharing economy depending on the platform orientation (i.e., for- or not-for-profit) [60-62], governance structure (i.e., democratic or centralized) [63-66] and ownership (i.e., collective or limited) are needed.

User behavior is also particularly crucial in the context of achieving net positive environmental impacts from sharing practices. "Accessing rather than owning", "second-hand consumption", and "donation" practices are deemed to increase resource efficiency through both (re)circulation of goods and utilization of durable assets and, more generally, to reduce consumption-induced environmental impacts such as waste generation or raw material extraction [67]. Consumer demand can increase when sharing practices make the provision of a particular service cheaper [3]. Additionally, the income gained (by providers and sellers) or freed (by takers and buyers) can be spent on other goods or services; the emissions (e.g., $\mathrm{CO}_{2}$ ) of this marginal expending can offset partly, fully, or be more higher than the initial gains [68]. This phenomenon is known as re-spending rebound effect [69]. In this respect, to establish how the net environmental impacts of for-profit platforms like Uber and Airbnb differ from platforms that promote a democratic relation among their participants (Fairmondo or Fairbnb.coop, for instance) is a cornerstone to delineate the environmental sustainability of the modern sharing movement. Therefore, a more refined understanding of why consumers engage in the sharing economy seems also crucial to guide the selection of the most suitable mechanism to safeguards the environmental benefits from resource sharing in its many forms.

Policy as well as platform providers can consider actions and incentives to minimize the unwanted rebound effect. The effectiveness of respective organizational practices, however, depends on a deep understanding of the mechanisms that drive behavioral change of individuals. It seems that the current literature lacks empirical evidence about the effectiveness of practices and a consideration of the particularities of the sharing economy. Hence, our current understanding does not provide actionable advice for platform providers to adapt their business models.

There is, therefore, a salient need to bring together leading sharing economy players using a change-driven approach more urgent than pointless debates about terms and definitions. Mechanisms that simultaneously lead consumers to engage in the modern sharing phenomenon actively and maximize the environmental gains from the use of sharing platforms need development and testing. These mechanisms should be tailored to specific users' groups based on their particular characteristics (motivations, preferences, consumption behavioral choices). Future research should consider the full spectrum of the sharing economy business models considered (C2C access, C2C shared ownership, B2C access, second-hand consumption, and donation). More specifically, we see the following as essential for an environmentally sustainable sharing economy:

1. A behavioral framework for analyzing sharing behaviors and related spending intentions;

2. Understanding of the root causes and quantifications of full environmental behavioral effects addressing the fundamental gap whether, to what extent, and under which conditions rebound effects undermine the environmental gains of the sharing economy; and

3. Systemic understanding of rebound effects that allows for exploring inconsistencies in values, motives, and actions, i.e., why and how consumers engaged in sharing platforms spend the freed and saved money (involving, thus, dissimilar rebound effects and subsequently, different net environmental impacts), in regards to platform orientation and governance. 


\section{Conclusions}

In this article, we reviewed and classified existing publications related to the sharing economy in multiple disciplines. Using the keywords "sharing economy", "collaborative economy," and "collaborative consumption", we extracted 942 unique publications from Scopus and Web of Knowledge published between 1978 and 2017. Four hundred and fifty-three (453) journal articles met the criteria for inclusion. These articles were in 284 different journals; 15 journals published five to 13 publications each and 221 journals had a single article about the topic. Journals from "business, management and accounting" (42.1\%) and "social sciences" (35.2\%) published more than $70 \%$ of the reviewed publications. The research has been focused consumers granting each other access to resources (i.e., transactions without transfer of ownership which mainly implies renting with monetary transactions). Accommodation and mobility were the dominating sectors, whereas other tangible (such as various type of objects) and intangible exchange (such as services, expertise, and ability) are rarely analyzed. Slightly more than half of the studies were empirical and qualitative approaches were dominant. We identified 27 different research methods. Literature review (22.9\%), survey (13.2\%), case study $(7.3 \%)$, and interview $(7 \%)$ were the four most frequently used methods. Using a grounded approach, we inductively identified the following five research clusters regarding the central theme being addressed in the publications: (1) user behavior (26.4\%), (2) business models and organizational aspects $(22.7 \%)$, (3) institution and governance system $(18.7 \%)$, (4) conceptualization matters $(17 \%)$, and (5) sustainability evaluation (15.3\%). Although user behavior was the largest cluster, the link between user behavior and net environmental impacts in diverse sharing sectors is an important area needing attention. Quantitative studies should explore the relations between the motives for participating in sharing economy and how (i.e., which consumption areas) users spending their earnings, the root causes, magnitude and likelihood of environmental rebound effects. Sharing platform providers should avoid making shallow claims of environmental benefits. Instead, they should spend their efforts towards driving the modern sharing phenomenon as a genuine mode of sustainable consumption.

Supplementary Materials: The following are available online at http://www.mdpi.com/2071-1050/11/20/5729/s1, Supplementary Material 1: Mapping database.

Author Contributions: Conceptualization, R.L.; methodology, R.L.; formal analysis, R.L., J.S., J.M.C., M.T. and R.S.; investigation, R.L., J.S., J.M.C., M.T. and R.S.; writing—original draft preparation, R.L., J.S., J.M.C., M.T. and R.S.; writing一review and editing, R.L.; visualization, R.L.

Funding: R.L. acknowledges the financial support from the Swiss Mobilier and the KTH Circular Economy Initiative (CE@KTH). J.S. recognizes financial support by the IIIEE Foundation (International Institute for Industrial Environmental Economics, i.e., Internationella Miljöinstitutet) and significant collaboration with the team of the Urban Sharing project, the project that has received funding from the European Research Council (ERC) under the European Union's Horizon 2020 research and innovation programme (grant agreement number 771872). R.S. acknowledges the financial support from FORMAS (project number 2018-01545).

Acknowledgments: The authors are thankful to Claudia R. Binder and Albert Merino-Saum for their comments on an early version of this article.

Conflicts of Interest: The authors declare no conflict of interest. The funders had no role in the design of the study; in the collection, analyses, or interpretation of data; in the writing of the manuscript, or in the decision to publish the results. 


\section{Appendix A}

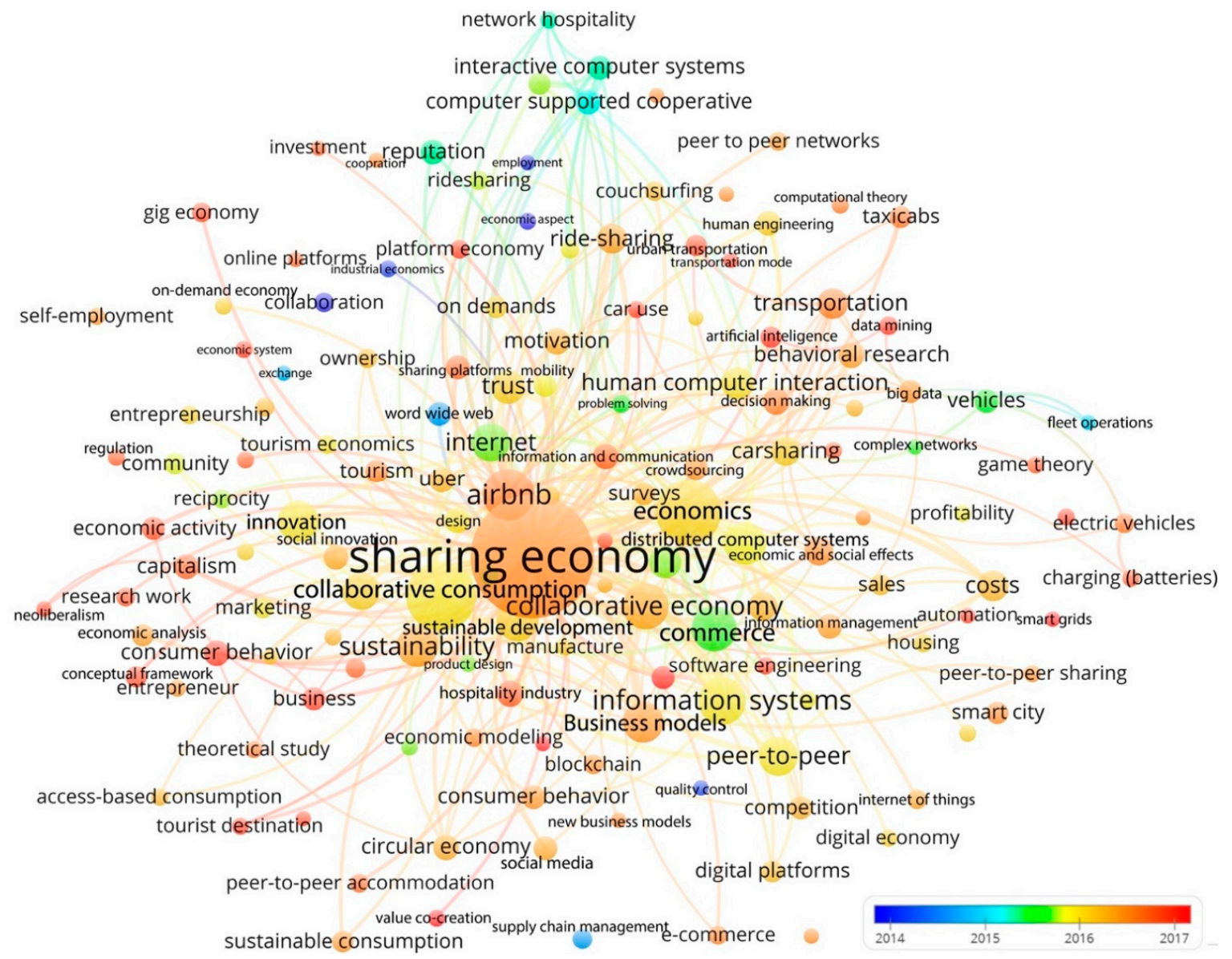

Figure A1. Term map out of the search string "sharing economy" OR "collaborative economy" OR "collaborative consumption" from Scopus.

Table A1. Breakdown of publication type and quantities after removing duplicates.

\begin{tabular}{cc}
\hline Publication Type & Quantity \\
\hline Journal article & 618 \\
Books & 53 \\
Book chapters & 19 \\
Conference paper & 252 \\
\hline
\end{tabular}

\section{Appendix B}

Table A2. Top 10 most cited publications accordingly to google scholar using the keywords "sharing economy", "collaborative consumption", and "collaborative economy". Retrieved on 25 June 2018.

\begin{tabular}{ccccc}
\hline Cities & Authors & Publication Title & Year & Source Title \\
\hline 2011 & $\begin{array}{c}\text { R Botsman, R } \\
\text { Rogers }\end{array}$ & $\begin{array}{c}\text { What's mine is yours: how collaborative } \\
\text { consumption is changing the way we live } \\
\text { You are what you can access: Sharing and } \\
\text { collaborative consumption online }\end{array}$ & 2011 & Book \\
R Belk & $\begin{array}{c}\text { J Hamari, M } \\
\text { Sjöklint, A } \\
\text { Ukkonen }\end{array}$ & $\begin{array}{c}\text { The sharing economy: Why people } \\
\text { participate in collaborative consumption }\end{array}$ & 2016 & $\begin{array}{c}\text { Journal of Business } \\
\text { Research }\end{array}$ \\
& $\begin{array}{c}\text { Journal of the Association } \\
\text { for Information Science } \\
\text { and Technology }\end{array}$ \\
\hline
\end{tabular}


Table A2. Cont.

\begin{tabular}{|c|c|c|c|c|}
\hline Cities & Authors & Publication Title & Year & Source Title \\
\hline 592 & $\begin{array}{l}\text { G Zervas, D } \\
\text { Proserpio, JW } \\
\text { Byers }\end{array}$ & $\begin{array}{l}\text { The rise of the sharing economy: } \\
\text { Estimating the impact of Airbnb on the } \\
\text { hotel industry }\end{array}$ & 2017 & $\begin{array}{l}\text { Journal of Marketing } \\
\text { Research }\end{array}$ \\
\hline 407 & J Schor & Debating the sharing economy. & 2016 & $\begin{array}{l}\text { Journal of Self-Governance } \\
\text { and Management } \\
\text { Economics }\end{array}$ \\
\hline 330 & A Sundararajan & $\begin{array}{l}\text { The sharing economy: The end of } \\
\text { employment and the rise of crowd-based } \\
\text { capitalism }\end{array}$ & 2016 & Book \\
\hline 318 & $\begin{array}{l}\text { M Felson, JL } \\
\text { Spaeth }\end{array}$ & $\begin{array}{l}\text { Community structure and collaborative } \\
\text { consumption: A routine activity approach }\end{array}$ & 1978 & $\begin{array}{l}\text { American Behavioral } \\
\text { Scientist }\end{array}$ \\
\hline 317 & $\begin{array}{l}\text { B Cohen, J } \\
\text { Kietzmann }\end{array}$ & $\begin{array}{c}\text { Ride on! Mobility business models for the } \\
\text { sharing economy }\end{array}$ & 2014 & $\begin{array}{l}\text { Organization and } \\
\text { Environment }\end{array}$ \\
\hline 292 & M Möhlmann & $\begin{array}{l}\text { Collaborative consumption: determinants } \\
\text { of satisfaction and the likelihood of using a } \\
\text { sharing economy option again }\end{array}$ & 2015 & $\begin{array}{l}\text { Journal of Consumer } \\
\text { Behaviour }\end{array}$ \\
\hline 260 & CJ Martin & $\begin{array}{c}\text { The sharing economy: A pathway to } \\
\text { sustainability or a nightmarish form of } \\
\text { neoliberal capitalism? }\end{array}$ & 2016 & Ecological Economics \\
\hline
\end{tabular}

Table A3. Journal special issues on the sharing economy.

\begin{tabular}{|c|c|c|}
\hline Publication Year & Special Issue Title & Journal Title \\
\hline 2016 & Regulating the sharing economy & Internet Policy Review \\
\hline 2016 & The risks and opportunities of the sharing economy & $\begin{array}{l}\text { European Journal of Risk } \\
\text { Regulation }\end{array}$ \\
\hline 2016 & Mobility and the sharing economy & Transport Policy \\
\hline 2016 & $\begin{array}{c}\text { The City as a Lab: open innovation meets the } \\
\text { collaborative economy }\end{array}$ & California Management Review \\
\hline 2017 & $\begin{array}{c}\text { Promises and paradoxes of the sharing economy: An } \\
\text { organizing framework }\end{array}$ & $\begin{array}{l}\text { Technological Forecasting and } \\
\text { Social Change }\end{array}$ \\
\hline 2017 & Sustainability perspectives on the sharing economy & $\begin{array}{l}\text { Environmental Innovation and } \\
\text { Societal Transitions }\end{array}$ \\
\hline 2017 & $\begin{array}{c}\text { The Sharing Economy: Opportunities and Challenges for } \\
\text { Marketing Channels and Supply Chains }\end{array}$ & Journal of Marketing Channels \\
\hline 2017 & $\begin{array}{l}\text { Shared responsibility and blurring boundaries: Strategic } \\
\text { implications of the sharing economy }\end{array}$ & MIS Quarterly Executive \\
\hline 2017 & Platforms and Ecosystems & $\begin{array}{l}\text { Technology Innovation } \\
\text { Management Review }\end{array}$ \\
\hline 2017 & $\begin{array}{l}\text { The Silicon Valley Ethos: Tech Industry Products, } \\
\text { Discourses, and Practices }\end{array}$ & Television and New Media \\
\hline
\end{tabular}

\section{References}

1. Laurenti, R.; Sinha, R.; Singh, J.; Frostell, B. Towards Addressing Unintended Environmental Consequences: A Planning Framework. Sustain. Dev. 2016, 24, 1-17. [CrossRef]

2. Prior, T.; Giurco, D.; Mudd, G.; Mason, L.; Behrisch, J. Resource depletion, peak minerals and the implications for sustainable resource management. Glob. Environ. Chang. 2012, 22, 577-587. [CrossRef]

3. Frenken, K.; Schor, J. Putting the sharing economy into perspective. Environ. Innov. Soc. Transitions 2017, 23, 3-10. [CrossRef]

4. Botsman, R.; Rogers, R. What's Mine Is Yours: How Collaborative Consumption is Changing the Way We Live; HarperCollins Publishers: New York, NY, USA, 2011; ISBN 9780061963551.

5. Belk, R. Sharing versus pseudo-sharing in web 2.0. Anthropologist 2014, 18, 7-23. [CrossRef]

6. Richardson, L. Performing the sharing economy. Geoforum 2015, 67, 121-129. [CrossRef]

7. Puschmann, T.; Alt, R. Sharing economy. Bus. Inf. Syst. Eng. 2016, 58, 93-99. [CrossRef]

8. Cherry, C.E.; Pidgeon, N.F. Is sharing the solution? Exploring public acceptability of the sharing economy. J. Clean. Prod. 2018, 195, 939-948. [CrossRef] 
9. Bucher, E.; Fieseler, C.; Lutz, C. What's mine is yours (for a nominal fee)-Exploring the spectrum of utilitarian to altruistic motives for Internet-mediated sharing. Comput. Hum. Behav. 2016, 62, 316-326. [CrossRef]

10. Dreyer, B.; Lüdeke-Freund, F.; Hamann, R.; Faccer, K. Upsides and downsides of the sharing economy: Collaborative consumption business models' stakeholder value impacts and their relationship to context. Technol. Forecast. Soc. Chang. 2017, 125, 87-104. [CrossRef]

11. Godelnik, R. Millennials and the sharing economy: Lessons from a 'buy nothing new, share everything month' project. Environ. Innov. Soc. Transit. 2017, 23, 40-52. [CrossRef]

12. James, K.L.; Randall, N.P.; Haddaway, N.R. A methodology for systematic mapping in environmental sciences. Environ. Evid. 2016, 5, 7. [CrossRef]

13. Price, J.A. Sharing: The Integration of Intimate Economies. Anthropologica 1975, 17, 3-27. [CrossRef]

14. Cotrim, J.M.O.; Nunes, F. Sharing Economy: The Establishment of Organizational Identity Overtime, Considering Identify Claims and Legitimacy Granting. Eur. J. Econ. Bus. Stud. 2017. [CrossRef]

15. Mauss, M. Essai Sur Le Don Forme Et Raison De L'échange Dans Les Sociétés Archaïquès. “The gift: The form and reason for exchange in archaic societies". L'Année Sociol. 1923, 1, 30-186.

16. Hyde, L. The Gift: Imagination and the Erotic Life of Property; Vintage Books: New York, NY, USA, 1983; ISBN 0-394-71519-5.

17. Hyde, L. Common As Air: Revolution, Art, and Ownership; Farrar, Straus and Giroux: New York, NY, USA, 2010; ISBN 0374532796.

18. Lessig, L. Remix: Making Art and Commerce Thrive in the Hybrid Economy; Bloomsbury Academic: London, UK, 2008.

19. Belk, R. Sharing. J. Consum. Res. 2010, 36, 715-734. [CrossRef]

20. Curtis, S.K.; Lehner, M. Defining the sharing economy for sustainability. Sustainability 2019, 11, 567. [CrossRef]

21. Petersen, K.; Vakkalanka, S.; Kuzniarz, L. Guidelines for conducting systematic mapping studies in software engineering: An update. Inf. Softw. Technol. 2015, 64, 1-18. [CrossRef]

22. Petersen, K.; Feldt, R.; Mujtaba, S.M. Mattsson Systematic mapping studies in software engineering. In EASE'08 Proceedings of the 12th international conference on Evaluation and Assessment in Software Engineering, Bari, Italy, 26-27 June 2008; BCS Learning \& Development Ltd.: Swindon, UK, 2008; pp. 68-77.

23. Clapton, J.; Rutter, D.; Sharif, N. SCIE Systematic Mapping Guidance; SCIE: London, UK, 2009.

24. Randall, N.P.; James, K.L. The effectiveness of integrated farm management, organic farming and agri-environment schemes for conserving biodiversity in temperate Europe-A systematic map. Environ. Evid. 2012, 1, 4. [CrossRef]

25. Grant, M.J.; Booth, A. A typology of reviews: An analysis of 14 review types and associated methodologies. Heal. Inf. Libr. J. 2009, 26, 91-108. [CrossRef]

26. Van Eck, N.J.; Waltman, L. Software survey: VOSviewer, a computer program for bibliometric mapping. Scientometrics 2010, 84, 523-538. [CrossRef]

27. Hamari, J.; Sjöklint, M.; Ukkonen, A. The sharing economy: Why people participate in collaborative consumption. J. Assoc. Inf. Sci. Technol. 2016, 67, 2047-2059. [CrossRef]

28. Plewnia, F.; Guenther, E. Mapping the sharing economy for sustainability research. Manag. Decis. 2018, 56, 570-583. [CrossRef]

29. Trenz, M.; Frey, A.; Veit, D. Disentangling the facets of sharing: A categorization of what we know and don't know about the Sharing Economy. Internet Res. 2018, 28, 888-925. [CrossRef]

30. Charmaz, K. Constructing Grouded Theory; SAGE Publications Ltd.: London, UK, 2014; ISBN 9788578110796.

31. Strauss, A.; Corbin, J. Grounded Theory Methodology: An Overview. In Handbook of Qualitative Research; Denzin, N.K., Lincoln, Y.S., Eds.; Sage Publications, Inc.: Thousand Oaks, CA, USA, 1994; pp. 273-285; ISBN 0803946791.

32. Felson, M.; Spaeth, J.L. Community Structure and Collaborative Consumption: A Routine Activity Approach. Am. Behav. Sci. 1978, 21, 614-624. [CrossRef]

33. Zamani, B.; Sandin, G.; Peters, G.M. Life cycle assessment of clothing libraries: Can collaborative consumption reduce the environmental impact of fast fashion? J. Clean. Prod. 2017, 162, 1368-1375. [CrossRef]

34. Möhlmann, M. Collaborative consumption: Determinants of satisfaction and the likelihood of using a sharing economy option again. J. Consum. Behav. 2015, 14, 193-207. [CrossRef] 
35. Cohen, B.; Kietzmann, J. Ride On! Mobility Business Models for the Sharing Economy. Organ. Environ. 2014, 27, 279-296. [CrossRef]

36. Täuscher, K.; Laudien, S.M. Understanding platform business models: A mixed methods study of marketplaces. Eur. Manag. J. 2018, 36, 319-329. [CrossRef]

37. Richter, C.; Kraus, S.; Brem, A.; Durst, S.; Giselbrecht, C. Digital entrepreneurship: Innovative business models for the sharing economy. Creat. Innov. Manag. 2017, 26, 300-310. [CrossRef]

38. Pfeffer-Gillett, A. When "disruption" collides with accountability: Holding ridesharing companies liable for acts of their drivers. Calif. Law Rev. 2016, 104, 233-268.

39. McKee, D. Neoliberalism and the legality of peer platform markets. Environ. Innov. Soc. Transit. 2017, 23, 105-113. [CrossRef]

40. Minter, K. Negotiating labour standards in the gig economy: Airtasker and Unions New South Wales. Econ. Labour Relat. Rev. 2017, 28, 438-454. [CrossRef]

41. Gruszka, K. Framing the collaborative economy - Voices of contestation. Environ. Innov. Soc. Transit. 2017, 23, 92-104. [CrossRef]

42. Zwick, A. Welcome to the Gig Economy: Neoliberal industrial relations and the case of Uber. GeoJournal 2017, 1-13. [CrossRef]

43. Ala-Mantila, S.; Ottelin, J.; Heinonen, J.; Junnila, S. To each their own? The greenhouse gas impacts of intra-household sharing in different urban zones. J. Clean. Prod. 2016, 135, 356-367. [CrossRef]

44. Fang, B.; Ye, Q.; Law, R. Effect of sharing economy on tourism industry employment. Ann. Tour. Res. 2016, 57, 264-267. [CrossRef]

45. Philip, H.E.; Ozanne, L.K.; Ballantine, P.W. Examining temporary disposition and acquisition in peer-to-peer renting. J. Mark. Manag. 2015, 31, 1310-1332. [CrossRef]

46. Corciolani, M.; Dalli, D. Gift-giving, sharing and commodity exchange at Bookcrossing.com: New insights from a qualitative analysis. Manag. Decis. 2014, 52, 755-776. [CrossRef]

47. Parguel, B.; Lunardo, R.; Benoit-Moreau, F. Sustainability of the sharing economy in question: When second-hand peer-to-peer platforms stimulate indulgent consumption. Technol. Forecast. Soc. Chang. 2017, 125, 48-57. [CrossRef]

48. Forno, F.; Garibaldi, R. Sharing Economy in Travel and Tourism: The Case of Home-Swapping in Italy. J. Qual. Assur. Hosp. Tour. 2015, 16, 202-220. [CrossRef]

49. Piscicelli, L.; Cooper, T.; Fisher, T. The role of values in collaborative consumption: Insights from a product-service system for lending and borrowing in the UK. J. Clean. Prod. 2015, 97, 21-29. [CrossRef]

50. Chi, H.; Zhou, W.; Piramuthu, S. Temporal ownership boundary in sharing economy. In Workshop on E-Business; Lecture Notes in Business Information Processing; Springer: Berlin, Germany, 2017; Volume 296, pp. 54-66.

51. Henten, A.H.; Windekilde, I.M. Transaction costs and the sharing economy. Info 2016, 18, 1-15. [CrossRef]

52. Todoli-Signes, A. The end of the subordinate worker?: The on-demand economy, the Gig Economy, and the need for protection for crowdworkers. Int. J. Comp. Labour Law Ind. Relat. 2017, 33, 241-268.

53. Scaraboto, D. Selling, sharing, and everything in between: The hybrid economies of collaborative networks. J. Consum. Res. 2015, 42, 152-176. [CrossRef]

54. Ambrosino, G.; Nelson, J.D.; Boero, M.; Pettinelli, I. Enabling intermodal urban transport through complementary services: From Flexible Mobility Services to the Shared Use Mobility Agency: Workshop 4. Developing inter-modal transport systems. Res. Transp. Econ. 2016, 59, 179-184. [CrossRef]

55. Miller, S.R. First principles for regulating the sharing economy. Harvard J. Legis. 2016, 53, 147-202. [CrossRef]

56. Lan, J.; Ma, Y.; Zhu, D.; Mangalagiu, D.; Thornton, T.F. Enabling value co-creation in the sharing economy: The case of mobike. Sustainability 2017, 9, 1504. [CrossRef]

57. Breidbach, C.F.; Brodie, R.J. Engagement platforms in the sharing economy: Conceptual foundations and research directions. J. Serv. Theory Pract. 2017, 27, 761-777. [CrossRef]

58. Martin, C.J. The sharing economy: A pathway to sustainability or a nightmarish form of neoliberal capitalism? Ecol. Econ. 2016, 121, 149-159. [CrossRef]

59. Rejeski, D. The post-ownership society. Environ. Forum 2017, 34, 38-41.

60. Böcker, L.; Meelen, T. Sharing for people, planet or profit? Analysing motivations for intended sharing economy participation. Environ. Innov. Soc. Transit. 2017, 23, 28-39. [CrossRef] 
61. Wirtz, J.; So, K.K.F.; Mody, M.A.; Liu, S.Q.; Chun, H.H. Platforms in the peer-to-peer sharing economy. J. Serv. Manag. 2019. [CrossRef]

62. McArthur, E. Many-to-many exchange without money: Why people share their resources. Consum. Mark. Cult. 2015, 18, 239-256. [CrossRef]

63. Schor, J. Debating the Sharing Economy; Great Transition Initiative; Tellus Institute: Cambridge, MA, USA, 2014.

64. Pitt, J.; Diaconescu, A. Structure and governance of communities for the digital society. In Proceedings of the 2015 IEEE International Conference on Autonomic Computing, Grenoble, France, 7-10 July 2015; Lalanda, P., Ed.; Institute of Electrical and Electronics Engineers Inc.: London, UK, 2015; pp. 279-284.

65. Mair, J.; Reischauer, G. Capturing the dynamics of the sharing economy: Institutional research on the plural forms and practices of sharing economy organizations. Technol. Forecast. Soc. Chang. 2016. [CrossRef]

66. Hartl, B.; Hofmann, E.; Kirchler, E. Do we need rules for "what's mine is yours"? Governance in collaborative consumption communities. J. Bus. Res. 2016, 69, 2756-2763. [CrossRef]

67. Geissinger, A.; Laurell, C.; Öberg, C.; Sandström, C. How sustainable is the sharing economy? On the sustainability connotations of sharing economy platforms. J. Clean. Prod. 2019, 206, 419-429. [CrossRef]

68. Laurenti, R.; Singh, J.; Sinha, R.; Potting, J.; Frostell, B. Unintended Environmental Consequences of Improvement Actions: A Qualitative Analysis of Systems' Structure and Behavior. Syst. Res. Behav. Sci. 2016, 33, 381-399. [CrossRef]

69. Font Vivanco, D.; McDowall, W.; Freire-González, J.; Kemp, R.; van der Voet, E. The foundations of the environmental rebound effect and its contribution towards a general framework. Ecol. Econ. 2016, 125, 60-69. [CrossRef]

(C) 2019 by the authors. Licensee MDPI, Basel, Switzerland. This article is an open access article distributed under the terms and conditions of the Creative Commons Attribution (CC BY) license (http://creativecommons.org/licenses/by/4.0/). 